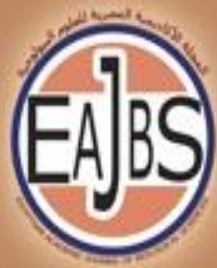

EGYPTIAN ACADEMIC JOURNAL OF
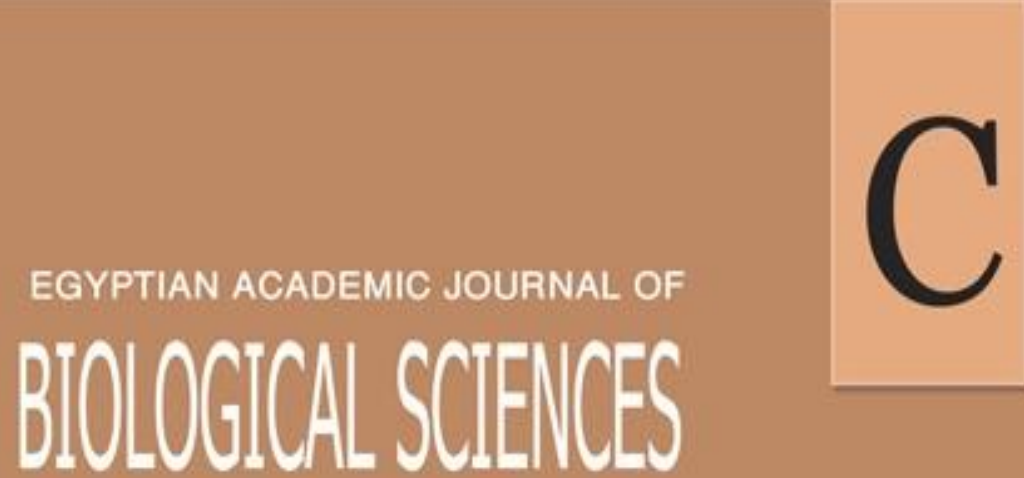

PHYSIOLOGY \& MOLECULARBIOLOGY
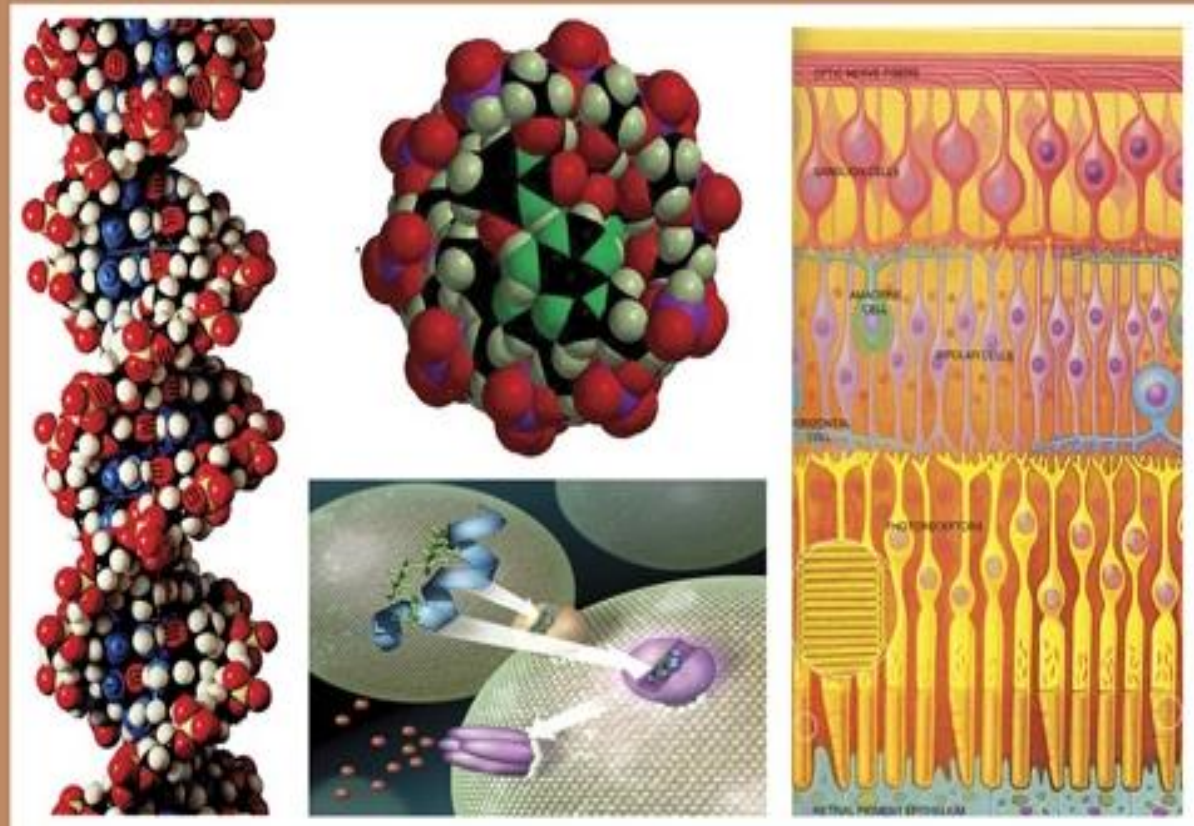

ISSN

2090-0767

WWW.EAJBS.EG.NET

Vol. 13 No. 2 (2021) 
Egypt. Acad. J. Biolog. Sci., 13(2):143-153 (2021)

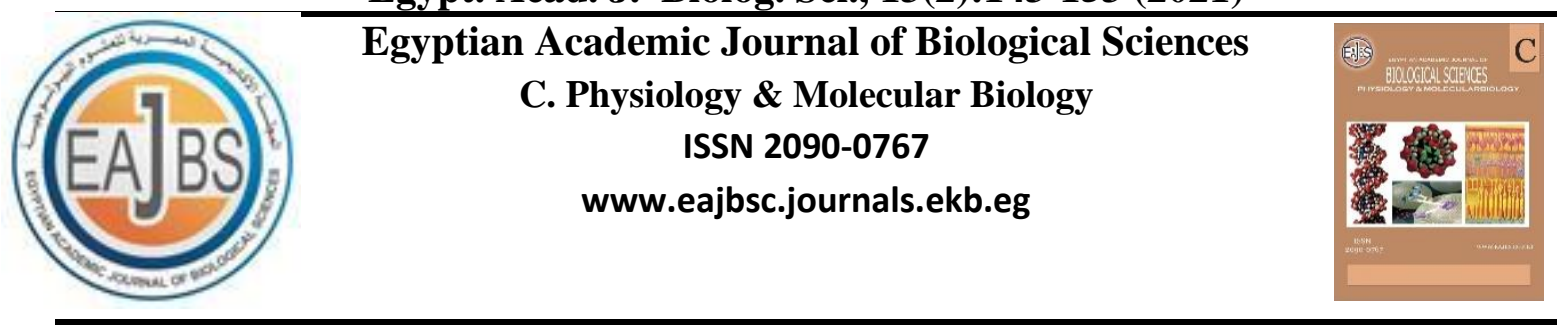

\title{
Isolation, Culture, Expansion and Characterization of Cord Blood-Derived Mesenchymal Stem Cells
}

\author{
Ahmed M. Abdelaziz ${ }^{1,2}$, Olfat G. Shaker ${ }^{3}$, Ahmed B. M. Mehany ${ }^{4}$ and Sayed \\ Bakry ${ }^{4}$ \\ 1-Ahmed Maher Teaching Hospital AMTH, Cairo. Egypt. \\ 2-Supplemntary General Sciences department, Future University in Egypt, Cairo, Egypt \\ 3-Medical Biochemistry and Molecular Biology Department, Faculty of Medicine, Cairo \\ University, Cairo, Egypt. \\ 4-Zoology department, Faculty of Science, Al-Azhar University, Cairo, Egypt. \\ *E. Mail : aabdelaziz83@yahoo.com - Olfat.shaker@kasralainy.edu.eg - \\ Abelal_81@yahoo.com - sbakry@azhar.edu.eg
}

\section{ARTICLE INFO}

Article History

Received:27/9/2021

Accepted:2/11/2021

Keywords:

Mesenchymal stem cells, Umbilical cord blood, osteogenic differentiation, flow cytometer.

\section{INTRODUCTION}

\section{ABSTRACT}

Mesenchymal stem cells MSCs were considered one of the most cells that contributed to research related to stem cells applications. And one of the most applied cells in cell therapy and clinical trials. Many sources were used to extract MSCs such as bone marrow, adipose tissue, pulp tissue, umbilical cord and cord blood. In this work cord blood was the source of cells due to its easy way to obtain and the easy way to process in the cell culture laboratory. The cord blood samples were processed inside safety cabinet class II to separate mononuclear cells first then the steps of isolation of MSCs comes later with culturing inappropriate media (DMEM, Fetal Bovine Serum FBS, L-Glutamine LG and penicillin-streptomycin) and conditions (temperature and $\mathrm{CO} 2$ ) to obtain pure mesenchymal stem cells after primary culture, subculture one and subculture two. The cells were characterized later with applied osteogenic differentiation to test MSCs capability to produce osteoblast. Cells show positive toward stains of calcium deposits of osteoblast (Von Kossa and Alizarine red S). The characterization also was achieved by using a flow cytometer to measure the reaction of MSCs toward the cell surface markers like CD 34, 45, 105 and 90. Cells show positive towards CD90 and 105 and negative toward CD 34 and 45. The methods applied for culturing and expansion mesenchymal stem cells in this work were suitable for yielding the number of the pure cell for further work. Also, the characterization methods (osteogenic differentiation, cell surface marker and morphology) were enough to identify mesenchymal stem cells.

The scientists take many steps to coin the term of mesenchymal stem cells, Friedenstein and Owen named these cells which isolated from bone marrow tissue "Osteogenic stem cells" or "Bone Marrow Stromal Cells." (Friedenstein et al., 1987), (Owen et al., 1988) Later, Caplan introduced the term mesenchymal stem cells referring to adult bone marrow progenitor cells with similar properties. (Caplan et al., 1991). 
The term mesenchymal stem cells have since then mostly and inaccurately been used for culture-derived stromal cell products, which have raised considerable interest as cell therapy tools for a number of disorders. (Doorn J et al., 2012). For example, MSCs have been demonstrated to be therapeutically effective in diseases, such as graft-versus-host disease. (Le Blanc et al., 2008). However, the widespread clinical use of cultured MSCs has been criticized, (Bianco et al., 2013) and an increasing number of unproven cell-based therapies outside of approved clinical trials has been made commercially available in recent years, which certainly is a major concern in current MSC therapy (Anastasio et al., 2010), (Deans et al., 2016)

MSCs can be retrospectively identified on the basis of their ability to form adherent colonies in vitro, and these cells were in analogy to the terminology used for the hematopoietic systemdesignated as CFU-Fs. (Friedenstein et al., 1974) MSCs have been labeled in a number of different species, where they can be isolated from various tissues. Isolation is usually based on the typical capacity of MSCs to adhere to plastic surfaces. (Da silva et al., 2006) ( Beltrami et al., 2007) (Arufe et al., 2009). One disadvantage of isolating cells by adherence, however, is the non-specificity of this approach regardless of the use of selected sera and media for culture initiation. This is due to the point that MSCs represent only a very rare fraction of the starting cell population that contains other, more abundant cells types, several of which also adhere to standard cell culture surfaces. Thus, MSC cultures started with non-selected cells are heterogeneous, and unwanted interactions of MSCs with non-MSCs might occur.

Prolonged culture is often necessary to remove the other cells and to obtain a reasonably pure MSC population. Stromal cells in general have a high proliferation capacity and are relatively easy to cultivate, and a number of commercial media formulations have been presented in the last years. These media save laborious and time-consuming serum testing and also allow better comparisons of results between laboratories, as the products are more regular compared to investigator-designed media. However, on the other hand, the exact composition of proprietary media might not be known, which is a potential problem when interpreting possible culture-induced MSC changes. Most information about MSCs relies on in vitro culture-expanded cells, which are now better referred to as multipotent MSCs (Horwitz et al., 2005) even better as cultured mesenchymal stromal cells or cultured stromal cells. These cultured stromal cell preparations have to fulfill a number of simple criteria to be classified as MSCs, including plastic adherence in standard media, an MSCtypical surface marker profile (expression of CD105, CD73, and CD90, and lacking expression of CD45, CD34 surface molecules) and in vitro differentiation potential toward the adipogenic, osteogenic, and chondrogenic lineages. (Dominici et al., 2006)

However, cultured mesenchymal stromal cell preparations are not homogeneous, (Tormin et al., 2009) and, more importantly, they do not necessarily reflect the properties of the native primary MSCs. Native primary MSCs, however, constitute the related cell population when studying the physiological role of MSCs in situ, Furthermore, cultured MSCs have been confirmed to gradually lose selfrenewal property, they have a decreased multilineage differentiation potential, (Pevsner et al., 2011) a poor hematopoiesis-supporting function (Churchman et al., 2012) (Qian et al., 2012) and they fail to migrate to the BM. (Rombouts et al., 2003) Cultured MSCs also show a different surface marker profile when compared to the freshly 
isolated primary cells. For example, a variety of surface markers, such as CD44 and CD318, are highly expressed on cultured cells, but not on primary MSCs, (Battulua et al., 2009) while the expression of other markers, such as CD271, is rapidly down-regulated in culture. (Tormin et al., 2011) Additionally, there is evidence of marked global gene expression differences between freshly isolated and cultured cells. (Chrchman et al., 2012) ( Harichandan et al., 2013). The phenotypical changes from primary to cultured cells are probably due to the biochemical changes in MSCs as they adapt to the in vitro culture conditions and suggest fundamentally altered functional properties of cultured cells. Thus, when aiming to characterize the physiological role of MSC in normal and diseased BM, it appears to be most appropriate to study primary, prospectively isolated MSCs. However, despite its limitations, conventional MSC isolation and propagation in culture is still a valid option when aiming for large-scale stromal cell expansion for clinical applications.

\section{MATERIALS AND METHODS}

\section{Isolation And Culturing of Mesenchymal Stem Cells:}

Cord blood samples were derived from Ahmed Maher Teaching Hospital, Gynecology department from normal deliveries. The samples were taken after birth without any risk for babies or cases. A consent sheet was signed with all guidelines and rules of the hospital. The samples were transferred directly to the laboratory and processed under septic conditions in biological safety cabinet class II. The samples were directly diluted with $3 \mathrm{X}$ volume with phosphate-buffered saline PBS / EDTA (Invitrogen, fisher scientific, USA) then layered blood mixture $(6 \mathrm{ml})$ over ficoll $(3 \mathrm{ml})$ in conical falcon tube. Centrifugation was done at $1500 \mathrm{rpm}$ for 10 minutes. the buffy-coated layers were collected and washed well then cultured in tissue culture vessels (Griener bio-one, Germany) with polystyrene bottoms. In T-25 $\mathrm{cm}^{2}$ flasks, cells were seeded by density $0.5 * 10^{6}$ per flask in the primary cell culture phase. The media added for culture composed of DMEM (Invitrogen, ficherscientific, USA) as a basic medium enriched with $15 \%$ fetal bovine serum PBS, 2\% L-glutamine, $1 \%$ penicillin-streptomycin and Hepes Buffer (Invitrogen, ficherscientific, USA). The media was changed twice per week. The primary cell culture was prolonged for 12 days when cells cover the plate by 80 $90 \%$. At this point, the cells were treated by Trypsin/EDTA (Invitrogen, ficherscientific, USA $(0.05 \mathrm{mM})$ for detachment and transferred to the next phase, subculture one.

The cells were distributed in culture flasks $\left(\mathrm{T}-25 \mathrm{~cm}^{2}\right)$ with reduced seeding density $35^{*} 10^{3}$ per flask. Seven days later the cells were confluent at $80 \%$. The previous steps were repeated in subculture two which takes also about seven days to finished.

\section{Characterization of Mesenchymal Stem} Cells:

\section{Osteogenic Differentiation:}

Differentiation of mesenchymal stromal cells was started with passage three where cells became confluent at 80$90 \%$. The cells were incubated with osteogenic differentiation media which composed from DMEM low glucose 4.5 $\mathrm{mmol} / \mathrm{L}, 10 \%$ FBS, $1 \%$ L-glutamine, $1 \%$ penicillin-streptomycin, 2\% Hepes buffer, glycerol-phosphate (10mM), (Sigma, USA), Ascorbic acid $(50 \mu \mathrm{g} / \mathrm{ml})$, (Sigma, USA) and Dexamethasone $\left(10^{-7} \mathrm{M}\right)$. (Sigma, USA).

The cells were incubated in the prepared media for 2 weeks. Media was changed two times per week. The cells were examined and imaged every day to detect the onset of osteogenic differentiation, Alizarin red $\mathrm{s}$ (Sigma Aldrich) and von kossa stains (Sigma Aldrich) were used for the detection of osteogenic differentiation.

Calcium depositions of osteoblasts were detected through its reaction with 
Alizarin sulphate. Scarlet to red colour was a marker for positive results. Staining procedures were started by discarding the media over cells. The cells were washed by pre-warmed PBS. Fixation was done by incubating the cells with formaldehyde $4 \%$ for 30 minutes. The fixative was then removed and the cells were washed gently with distilled water. The alizarin red stain was added to merge all the cells for approximately 5 minutes. The stain was discarded and the cells were washed with distilled water and dried in the flask on air. Red patches in test groups were examined microscopically (inverted microscope) and it can be detected with a necked eye where it was absent in the control group.

Staining the cells with Von Kossa stain is slightly different than Alizarin red S. The cells were first fixed using formaldehyde 4\% (Al-Nasr comp. Egypt) for 30 minutes. Silver nitrate was added to cover the cells with exposure to high light for 50 minutes. The cells were then washed carefully using distilled water to eliminate all the debris of silver nitrate. Sodium thiosulfate solution was added and incubated with the cells for 5 minutes. The solution was discarded and the cells were washed. Then air-dried. The progress of the reaction was followed up visually. The staining intensity of brown to black color was a reference for the presence of calcium produced by differentiated osteoblasts.

\section{Flow Cytometer Characterization of Surface Markers of MSCs:}

After passaging the cells in the lab for three passages, samples from the cells were sent to the flow cytometer (MACS Quant x, Milteni Biotech, Germany) to be stained by the following markers: CD34PE, CD45-FITC, CD90- FITC and CD105-PE. The cells were detached and counted then concentrated in five vials. Every vial contains $1 \times 10^{6}$ cells in $100 \mu \mathrm{l}$ media. A special buffer was prepared in the laboratory for use in the flow measurements. Phosphate buffered saline with half volume bovine serum albumin. $2 \mu \mathrm{l}$ of antibodies were mixed well with 98 $\mu 1$ of cells in media, incubated at $2-8{ }^{0} \mathrm{C}$ for 10 minutes. cells were washed with $2 \mathrm{ml}$ of buffer centrifuged and the pellet was resuspended in $50 \mu 1$ of the special buffer then measured at the flow cytometer.

\section{RESULTS}

\section{Separation of mononuclear cells from cord blood samples:}

The count of mononuclear cells yields from the samples of cord blood which inter in the culture was ranged around $\left(3.7^{*} 10^{7}\right)$. Trypan blue was used to detect the viability of MNCs before separation of MSCs (Mean 93\%).

Table 1: Viability assay using trypan blue for cord blood samples

\begin{tabular}{|l|c|c|c|c|c|}
\hline & Sample I & Sample II & Sample III & Sample IV & Sample V \\
\hline Count & $3.6 \times 10^{7}$ & $4.3 \times 10^{7}$ & $3.8 \times 10^{7}$ & $3.9 \times 10^{7}$ & $2.9 \times 10^{7}$ \\
\hline Viability & $91 \%$ & $96 \%$ & $93 \%$ & $90 \%$ & $95 \%$ \\
\hline
\end{tabular}

Culturing of Mesenchymal Stem Cells:

In primary culture, the cells take some times to attach to the polystyrene face of the culture flask. The doubling times were measured by culturing cells in 24 plated and counting the cells each day till confluent state. The cells take 12 days to reach $85 \%$ confluent state and finalize the primary culture stage. The $1^{\text {st }}$ passage and $2^{\text {nd }}$ passage almost take the same time to be confluent about 7 days. The cells proliferate to raise the number of seeded cells $1.4 * 10^{4}$ to $8.3 * 10^{4}$ in the $1^{\text {st }}$ passage and $9.74 * 10^{4}$ in the $2^{\text {nd }}$ passage in 7 days. The doubling time of cells in $1^{\text {st }}$ passage was 28.37 hours with a doubling rate of 5.92 times while in $2^{\text {nd }}$ passage was 24.17 hours with a doubling rate of 6.95 times. The figures below show the cells' morphology and growth curve during primary and passages of culture. 

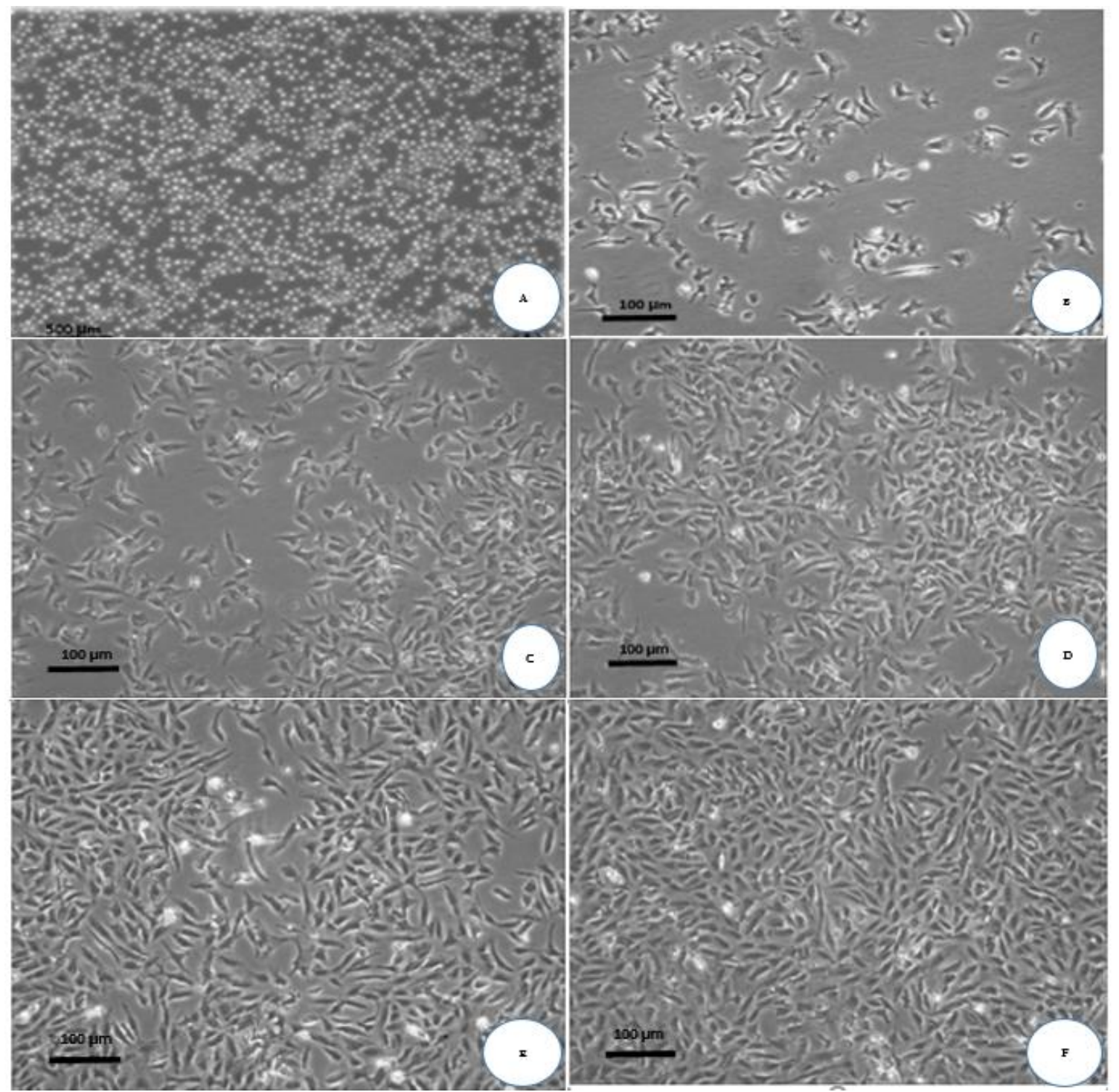

Fig. 1: show images of cells during primary culture (A) Cells at day zero 4X. (B) Cells at day three 10x. (C) Cells at day five 10X. (D) Cells at day seven 10X. (E) Cells at day nine 10X, (F) Cells at day twelve 10X.

Table2 Represent the numbers of cells which seeded and yielded in the primary, subculture one and subculture two. With the doubling time for each culture and the viability assay by trypan blue

\begin{tabular}{|c|c|c|c|c|c|}
\hline \multicolumn{6}{|c|}{$\begin{array}{l}\text { MSCs growth during primary subculture } 1 \text { and subculture two. (Count per } \mathrm{cm}^{2} * 10^{4} \pm \mathrm{SD} \text { ) Versus } \\
\text { days of culture }\end{array}$} \\
\hline \multirow{3}{*}{$\begin{array}{l}\text { Primary } \\
\text { culture }\end{array}$} & Day 0 & Day 3 & Day 6 & Day9 & Day 12 \\
\hline & $520 \pm 67.60$ & $3.98 \pm 0.114$ & $6.30 \pm 0.055$ & $8.95 \pm 0.156$ & $10.81 \pm 0.347$ \\
\hline & \multicolumn{5}{|c|}{$\begin{array}{l}\text { Doubling time of primary culture at the last nine days of culture reaches } 80.89 \text { hours. The } \\
\text { viability measured at the end of the passage reaches } 95 \% \text {. (The cells doubled } 2.67 \text { times) }\end{array}$} \\
\hline \multirow{3}{*}{$\begin{array}{l}\text { Subculture } \\
\text { one }\end{array}$} & Day 0 & Day 1 & Day 2 & Day 4 & Day 7 \\
\hline & $1.4 \pm 0$ & $1.704 \pm 0.128$ & $2.942 \pm 0.095$ & $5.004 \pm 0.555$ & $8.296 \pm 0.202$ \\
\hline & \multicolumn{5}{|c|}{$\begin{array}{c}\text { Doubling time of subculture one for the seven days (whole culture time) reaches } 28.37 \\
\text { hours. The viability is over } 95 \% \text {. (The cells doubled } 5.92 \text { times) }\end{array}$} \\
\hline \multirow{3}{*}{$\begin{array}{l}\text { Subculture } \\
\text { two }\end{array}$} & Day 0 & Day 1 & Day 2 & Day 4 & Day 7 \\
\hline & $1.4 \pm 0$ & $2.76 \pm 0.143$ & $4.918 \pm 0.104$ & $6.81 \pm 0.194$ & $9.74 \pm 0.306$ \\
\hline & \multicolumn{5}{|c|}{$\begin{array}{c}\text { Doubling time of the subculture two after seven days reaches } 24.17 \text { hours and viability } \\
\text { over } 95 \% \text {. (The cells doubled } 6.95 \text { times) }\end{array}$} \\
\hline
\end{tabular}



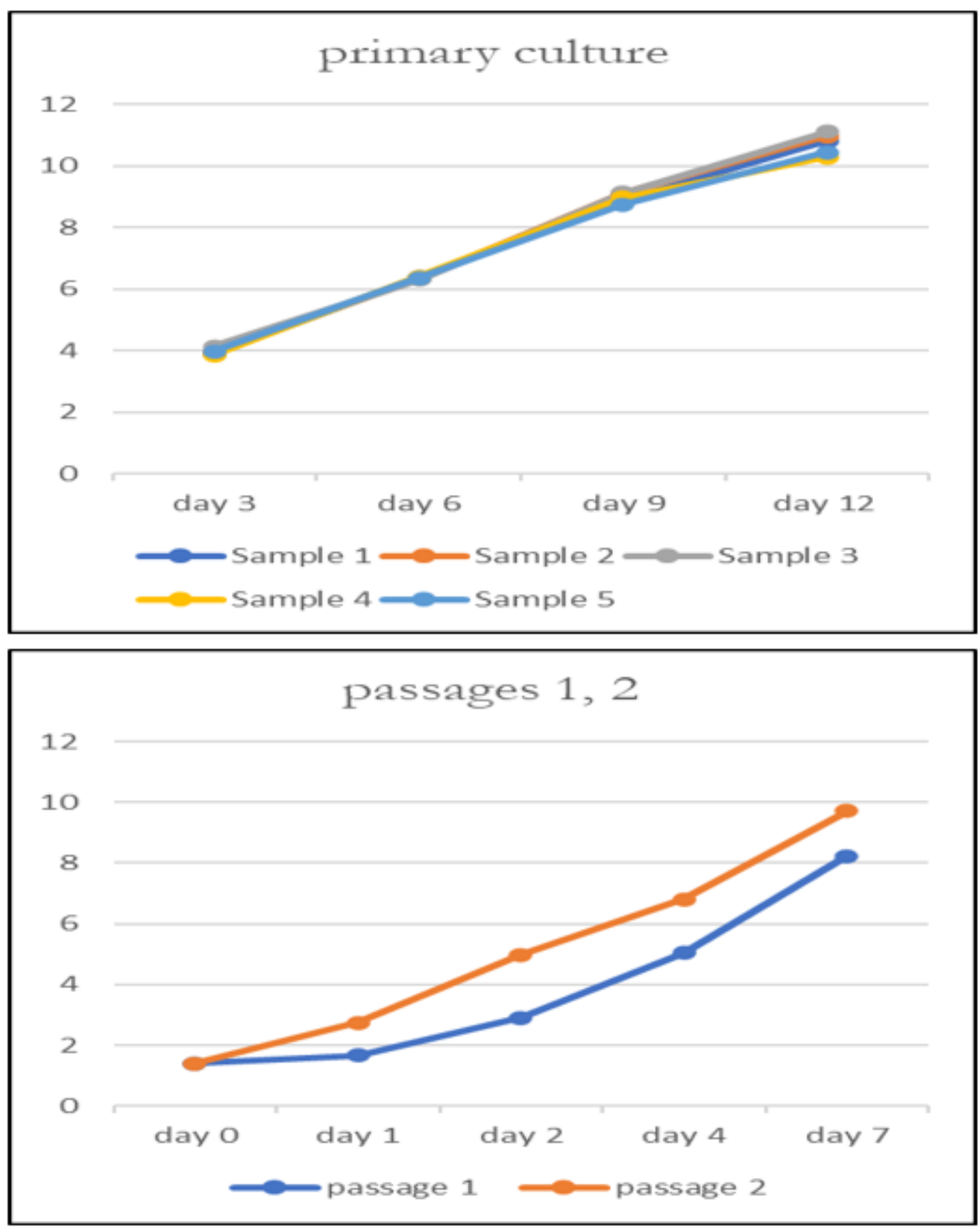

Fig.2 :Show the growth curve of MSCs during primary culture and subculture one and two from the culture point to the plateau point.

Characterization of Mesenchymal Stem Cells:

\section{Osteogenic Differentiation:}

Alizarin red $\mathrm{S}$ reacts with $\mathrm{Ca}++$ which is secreted from differentiated osteoblast and give red patches while von kossa stain gives brown to black patches. Both were obvious under an inverted microscope and can be detected via the naked eye. 

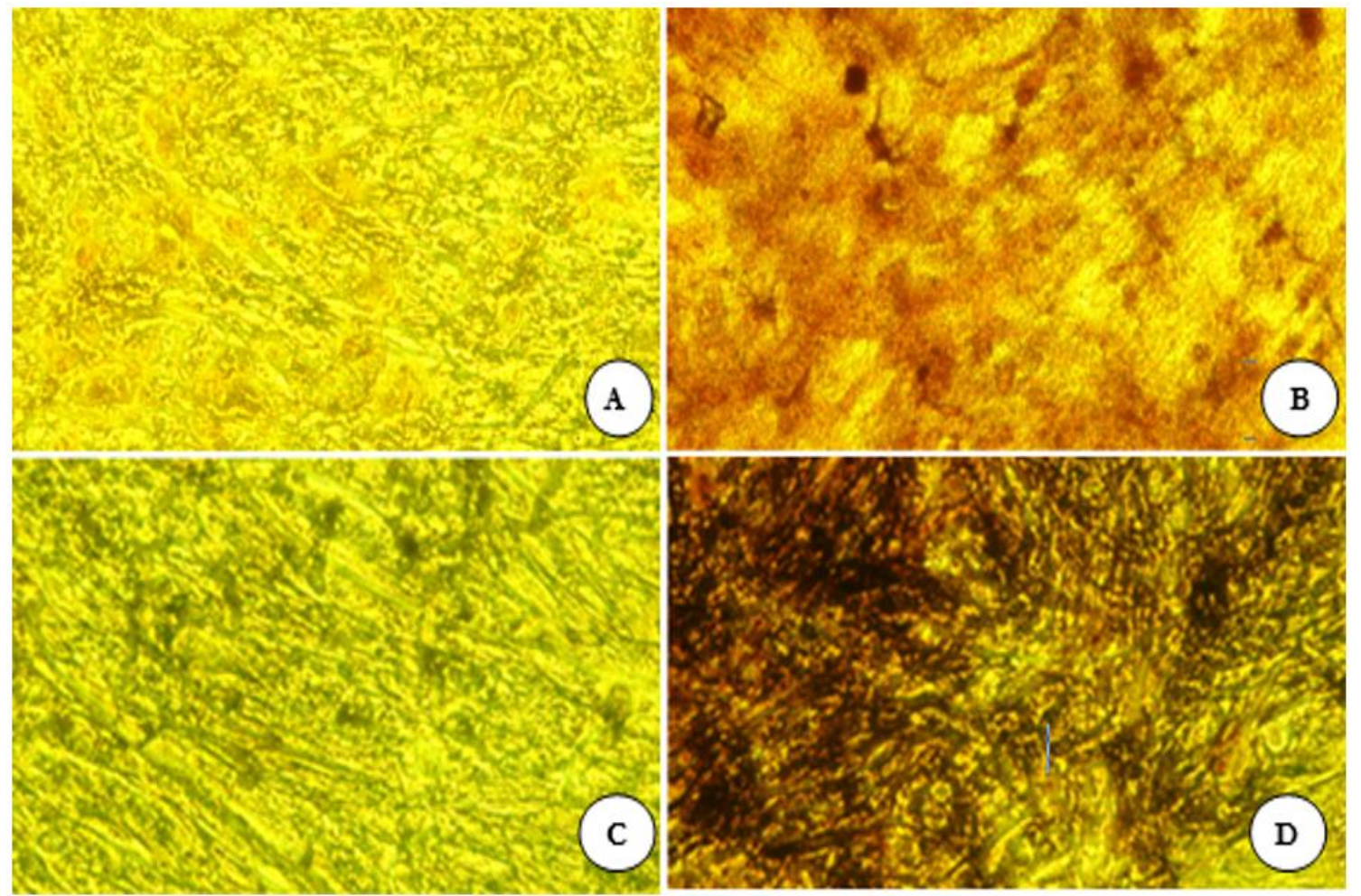

Fig.3 represent osteogenic differentiation of cord blood derived mesenchymal stem cells. (A) control cells stained with Alizarine red S stain (B) test group stained with Alizarine red $\mathrm{S}$ at day 7. Red patches refer to interaction between stain and calcium depositions secreted by ostegenic cells (C) control cells stained with von Kossa stain (D) test group stained with von Kossa at day 7. Brown to black patches refer to interaction between stain and calcium secreted by the cells.

Characterization of Mesenchymal Stem Cells:

Flow Cytometer Markers:

Four markers were used to detect and confirm the presence of mesenchymal stem cells. These markers are CD 34-PE, 45-FITC and CD90-FITC, 105-PE. All the markers \& software (MACs Quant analyzer) and flow cytometer (MACs Quant X) are derived from (Miltenyi Biotech Com, Germany). The cells were positive with CD90, 105 and negative with CD 34, 45 shown in the following figure 4. 


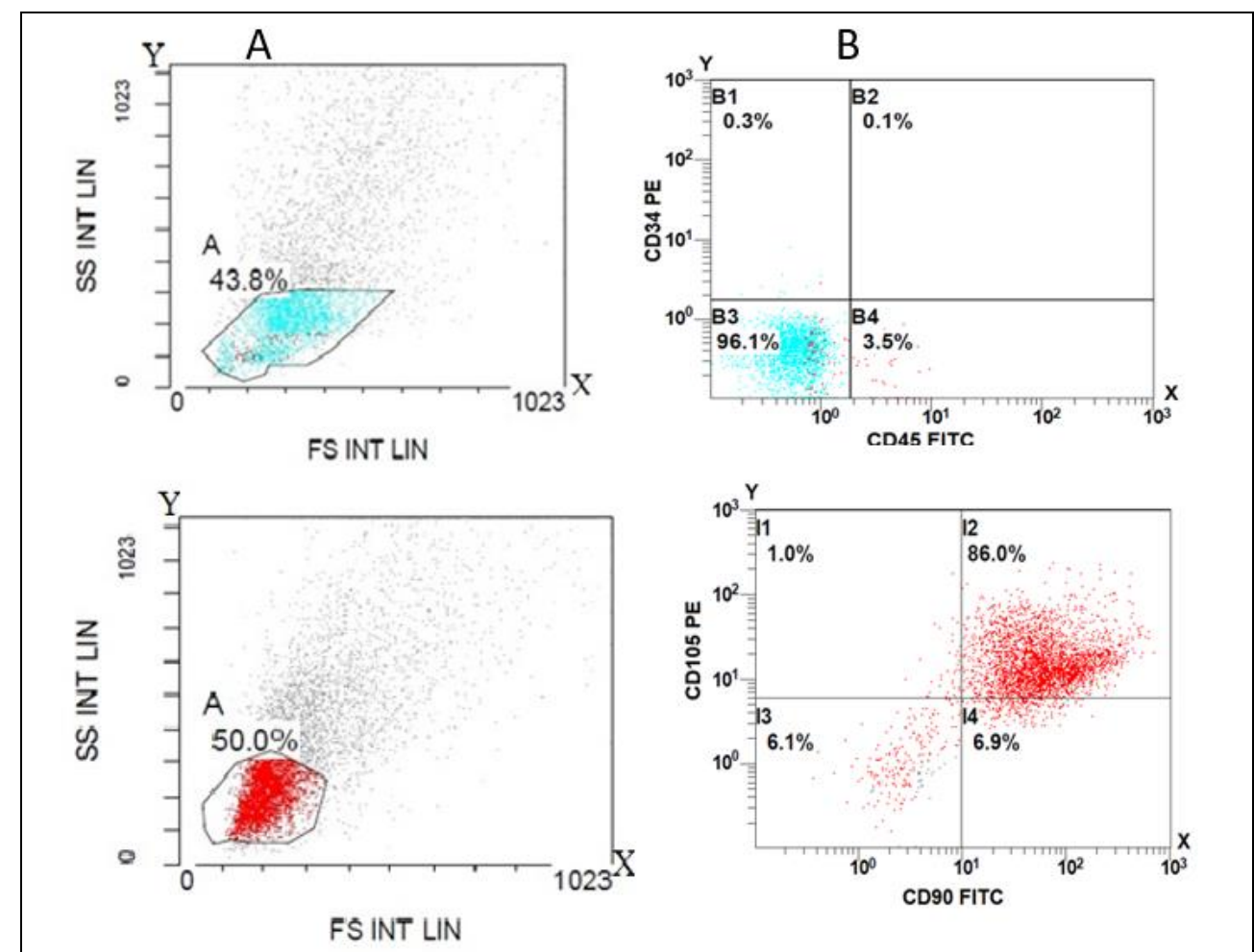

Fig.4 Flow cytometric characterization analyses of human umbilical cord blood-derived MSCs showing :ungated histogram (A) and gated histogram (B). the histograms show theta cells are positive for CD 90 and 105 and negative for CD 34 and 45

\section{DISCUSSION}

\section{MSCs Isolation and Culture:}

The methods which were used to isolate cells were chosen to obtain a high number of cells with the minimum amount of stress. The high viability of cells showed in table one returned to the double volume of dilution of blood with phosphate-buffered saline. And also, for the concentration of ficoll (separator media) which was $1.44 \mathrm{M}$. cell stacking was ignored by layering blood mixture over ficoll very carefully with no mixing between the layers and the transferring of tubes to centrifuge also performed gently and centrifugation was performed at 1500 $\mathrm{rpm}$ for 20 minutes. The centrifugation by the speed and time mentioned above gives separate cells without damage or rapture. (Shahdadfar et al., 2005)

Several techniques have been developed to obtain pure cultures of MSCs by the reduction or elimination of nonMSCs from cord blood cultures. This was achieved, in the present study, by the application of a prolonged expansion step through which all of the umbilical cordderived cells pass in primary culture and three subsequent passages. During this time, only MSCs, due to their adherent property, were retained in the culture while all of the other non-adherent cells were eliminated by washing during media change. Moreover, the selective medium and the polystyrene-coated tissue culture flasks enhanced the adhesion properties of only (Vater et al., 2011).

\section{Osteogenic Differentiation of Mesenchymal Stem Cells:}

In the current work, two stains were used to detect the osteogenic properties of mesenchymal stem cells. Alizarin red S and Von Kossa stains are widely used assays that respectively target anionic phosphates and calcium cations. The von Kossa method is based on the binding of silver ions to the anions (phosphates, sulfates, or carbonates) of calcium salts and the reduction of silver salts to form dark brown or black metallic silver staining. Unlike the non-specificity of von Kossa for calcium, alizarin red $S$ 
reacts with calcium cation to form a chelate. To stain the cells, the fixation step was performed which end the culture in both methods. (Hamodouche et al., 2008) Flow Cytometer Detection of MSCs:

Currently, there is no single marker for human mesenchymal stem cells. Therefore, we use a combination of markers to characterize the population. The international society of cellular therapies (ISCT) has proposed minimal criteria for true MSCs. These criteria include the ability to adhere to polystyrene-coated flaks and differentiation to adipose, chondrogenic and osteogenic lineages. And the expression of surface markers includes CD 90 and CD 105 also MSCs must lack the expression of CD 45, CD34 (Rasini et al., 2013). The flourochromes were $P E$ and FITC with colors blue and green. PE absorption/emission peak was settled at 495 / $575 \mathrm{~nm}$ so the reads were taken at blue color. While FITC absorption/emission peak was settled at 494 / $518 \mathrm{~nm}$ so the reads were taken green color. The results have met the results of the published article where the surface markers were positive with CD 90 and CD 105 while giving negative with CD 34 and CD 45. (Andrzejewska et al., 2019).

\section{REFERENCES}

Anastasio, A., Gergues,M., Lebhar, M., Rameshwar, P \& Moure, F. 2010, Isolation and characterization of mesenchymal stem cells in orthopedics and the emergence of compact bone mesenchymal stem cells as a promising surgical adjunct. World Journal of Stem Cells, 12(11): 1341-1353

Andrzejewska., A., Lukomska., B. \& janowski., M. 2019. Concise Review. Mesenchymal stem cells: from roots to boost. Stem cells. 10.1002

Arufe, M., Fuente, D. \& Fancisco, F. 2009. Differentiation of synovial $\quad$ CD- $105^{+}$human mesenchymal stem cells into chondrocyte-like cells through spheroid formation. Journal of Cell. Biochemistry, 108: 145- 155.

Battula, V., treml, S., Bareiss, M., Gieseke, F., Roelofs, H., Zwart, P., Muller, I., Schewe, B. \& Skutelle, T. 2009. Isolation of functionally distinct mesenchymal stem cell subsets using antibodies against CD56, CD271, and mesenchymal stem cell antigen1. Haematologica, 94: 173- 184.

Beltrami, A., Casselli, D., Bergamin, N., Macron, P., Rigo, S., Puppato, E., et al. 2007. Multipotent cells can be generated in vitro from several adult human organs (heart, liver, and bone marrow). Blood, 110: 3438- 3446.

Bianco, P., Cao, X., Fenette, J., Robey, P. 2013. The meaning, the sense and the significance: translating the science of mesenchymal stem cells into medicine. Nature Medicine, 19: 35- 42.

Caplan, A. 1991. Mesenchymal stem cells. Journal of Orthopaedics Research, 9: 641-650.

Churchman, S., Ponchel, F., Boxall, S., Cuthbert, R., Roshdy, T., Emery, P \& McGonagle, D. 2012. Transcriptional profile of native $\quad \mathrm{CD} 271^{+}$multipotential stromal cells: evidence for multiple fates, with prominent osteogenic and Wnt pathway signaling activity. Arthritis Rheum, 64: 2632- 2643.

da Silva, M., Chagastelles, L., \& Nardi, N. 2006. Mesenchymal stem cells reside in virtually all post-natal organs and tissues. Journal of. Cell Science. 119: 2204- 2213.

Deans, R., Gunter, K., Dominici, M., Forte, M. 2016. Unproven cell therapies and the commercialization of cell-based products. Cytotherapy, 18: 138142. 
Dominici, M., Blanc K., Muller, i., Cortenbach, S., Horwitz, E., Krause, D \& prokop, D. 2006. Minimal criteria for defining multipotent mesenchymal stromal cells. The International Society for Cellular Therapy position statement. Cytotherapy, 8: 315-317.

Doorn, J., Moll, G., Le Blanc, K., Blitterswijk, C. 2012. Therapeutic applications of mesenchymal stromal cells: paracrine effects and potential improvements. Tissue Engineering. Part B Review. 18: 101- 115.

Friedenstein, A. 1974. Precursors for fibroblasts in different populations of hematopoietic cells as detected by the in vitro colony assay method. Experemental.

Hematolology. 2: 83-92.

Friedenstein, A., Chailakhyan K. \&Gerasimov, U. 1987. Bone marrow osteogenic stem cells: in vitro cultivation and transplantation in diffusion chambers. Cell Tissue Kinetics, 20: 263-272

Hamidouche, Z., Hay, E., Vaudin, P., Charbord, P., Schule, R., Marie, P.J. \& Fromigue, O. 2008. FHL2 mediates dexamethasone-induced mesenchymal cell differentiation into osteoblasts by activating Wnt/beta-catenin signaling dependent Runx2 expression. Federation of American societies for experimental biology Journal, 22:3813-3822.

Harichandan, A., Sivasubramaniyan, K. \& Buhring, H.J. 2013. Prospective isolation and characterization of human bone marrow-derived MSCs. Advanced Biochemistery Engineering Biotechnology, 129: 1- 17.

Horwitz, E., Blanc, K., Dominici, M., Muller, i., Cortenbach, S., Marini, F., Deans, R., Krause, D \& Keating, A. 2005. Clarification of the nomenclature for MSC: the international society for cellular therapy position statement. Cytotherapy, 7: 393395.

Le Blanc, K., frassoni, F., Ball, L., Locatelli, F., Roelofs, H, Lanino, E. \& remberger M. 2008. Mesenchymal stem cells for treatment of steroid-resistant, severe, acute graft-versus-host disease: a phase II study. Lancet,371: 1579-1586

Owen, $\quad$ M. \& $\quad$ Friedenstein, A. 1988. Stromal stem cells: marrow-derived osteogenic precursors. Ciba Foundation Symposium, 136: 42-60.

Pevsner-Fischer, M., Levin, M \& Zipori, D. 2011. The origins of mesenchymal stromal cell heterogeneity. Stem Cell Revolution, 7: 560- 568.

Qian, H., Le Blanc, K. \& Sigvardsson. M. 2012. Primary mesenchymal stem and progenitor cells from bone marrow lack expression of CD44 protein. Journal of Biololgical Chemistry, 287: 25795-25807.

Rasini, V., Dominici, M., Kluba, T., Siegel, G., Lusenti, G., Northoff, H., Horwitz, EM. \& Schafer, R. 2013. Mesenchymal stromal/ stem cells markers in the human bone marrow. Cyto-therapy, 15:292-306 Rombouts, W. \& R.E. Ploemacher. 2003. Primary murine MSC show highly efficient homing to the bone marrow but lose homing ability following culture. Leukemia, 17: 160- 170.

Shahdadfar, A., Tronsdal, K. \& Haug, T. 2005. In vitro expansion of human mesenchymal stem cells: choice of serum is a determinant of cell proliferation., differentiation., gene expression., and transcriptome stability. Stem cells, 23:1357-1366

Tormin, A. Brune, j., Olsson, E., Valcich, j., Neuman, U \& Olofsson, 
T.. 2009. Characterization of bone marrow-derived mesenchymal stromal cells (MSC) based on gene expression profiling of functionally defined

MSC subsets. Cytotherapy, 11:114-128.

Tormin, A., Li, O., Brune, J., Walsh, S., Schutz, B.,Ehinger, M., Ditzel, N., \& Kassem, M. 2011. CD146 expression on primary nonhematopoietic bone marrow stem cells are correlated with in situ localization. Blood, 117: 50675077.

Vater, C., Kasten, P. \& Stiehler, M. 2011. Culture media for the differentiation of mesenchymal stromal cells. Acta Biomaterialia, 7:463-477.

\section{ARABIC SUMMARY}

\section{فصل وزراعة واكثار الخلايا الجذعية المتوسطة المستخرجة من دم الحبل السري واختبار دلالتها}

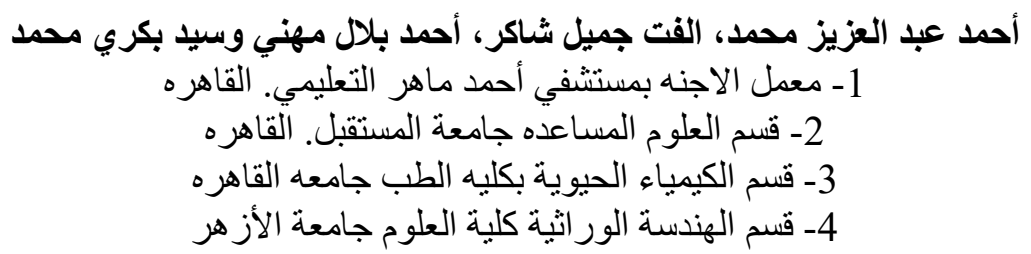

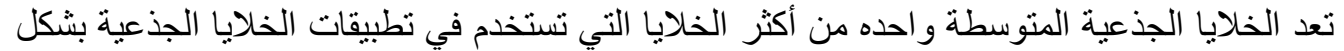

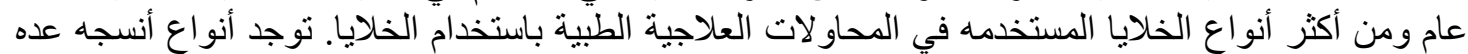

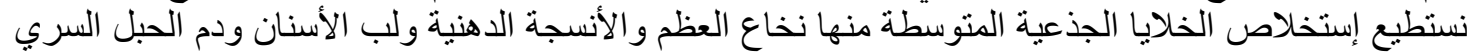

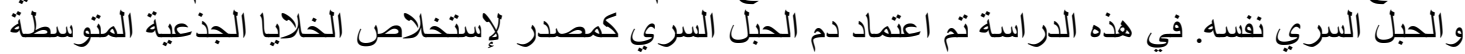

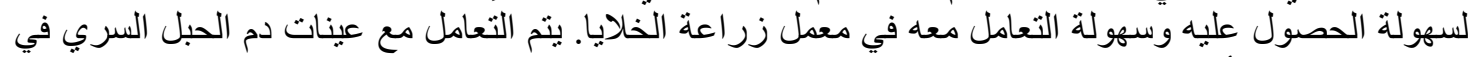

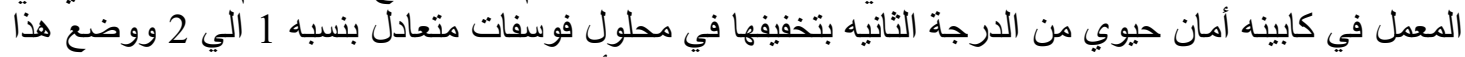

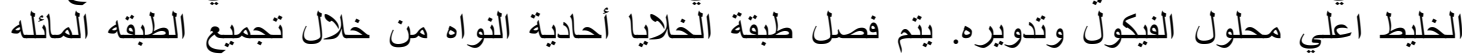

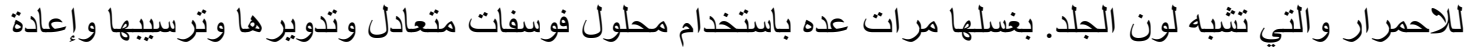

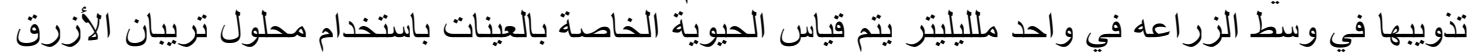

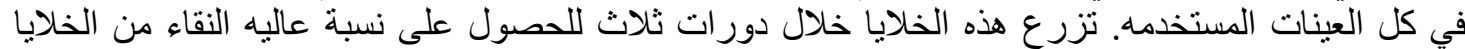

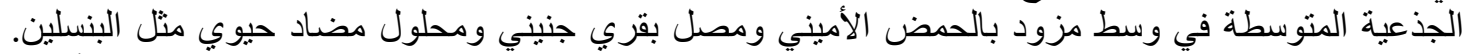

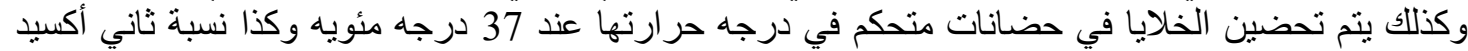

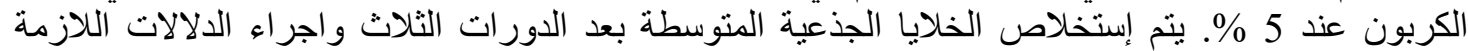

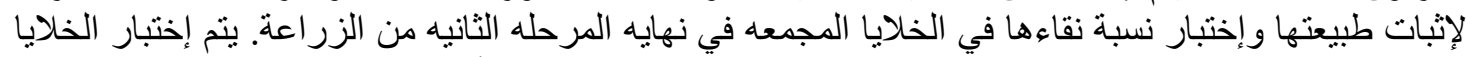

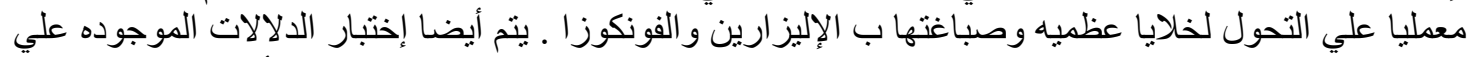

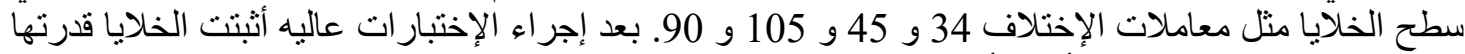
علي التحول لخلايا عظمية و أيضا أعطت نتيجة ايجابية مع معامل الإختلاف

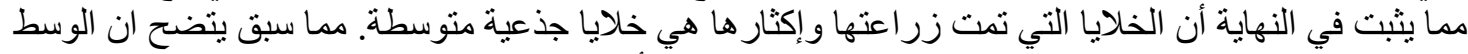

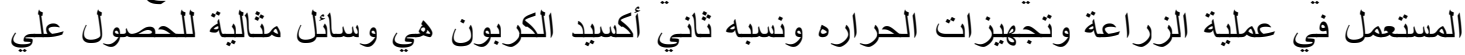

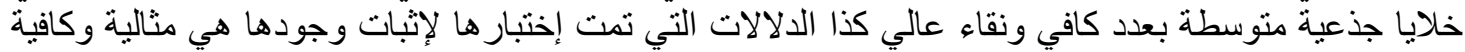
ل للإشاره بوضوح إلي الخلايا الجذّعية المتوسطة. 